\title{
Raritní komplikace při uzávěru defektu septa síní Amplatzovým okluderem
}

\author{
Martin Běhounek, Antonín Novák, Radim Špaček, Marian Bystroń, Jozef Jakabčin, Jan Dvořák*, Pavel Červinka \\ Kardiologická klinika, *Chirurgické oddělení, Krajská zdravotní a. S., Masarykova nemocnice, Ústí nad Labem, Česká republika
}

Úvod: Perkutánní uzávěry defektů na úrovni septa síní představují v současné době u většiny nemocných metodu první volby $\mathrm{v}$ léčbě těchto vrozených srdečních vad u dospělých pacientů. Jakkoli se jedná o metodu účinnou a bezpečnou, může být vlastní výkon provázen některými specifickými komplikacemi. Autoři popisují raritní př́pad embolizace Amplatzova okluderu do descendentní aorty.

Popis případu: 58letý nemocný s hemodynamicky významným defektem septa síní typu secundum byl indikován $\mathrm{k}$ uzávěru defektu pomocí Amplatzova okluderu. Výkon byl proveden v lokální anestezii $\mathrm{z}$ pravé společné stehenní žíly. Vzhledem $\mathrm{k}$ „stretched diametru“ $(11 \mathrm{~mm})$ byl zvolen okluder velikosti $15 \mathrm{~mm}$. Správné umístění okluderu bylo overéeno tzv. „Minnesota manévrem“. Rovněž následné odpoutání zařízení od zaváděcího katetru proběhlo bez komplikací. Kontinuálně prováděná transesofageální echokardiografie (TEE) zobrazovala optimální účinek výkonu. Př̀ poslední TEE kontrole však bylo pozorováno uvolnění Amplatzova okluderu z mezisíňové přepážky do volného prostoru levé síně (obrázek 1), kde se okluder již dále nezobrazoval. Okluder nebylo možno nalézt pomocí TEE $\mathrm{v}$ levostranných ani pravostranných srdečních oddílech a také rentgenovou skiaskopií nebyl vidět

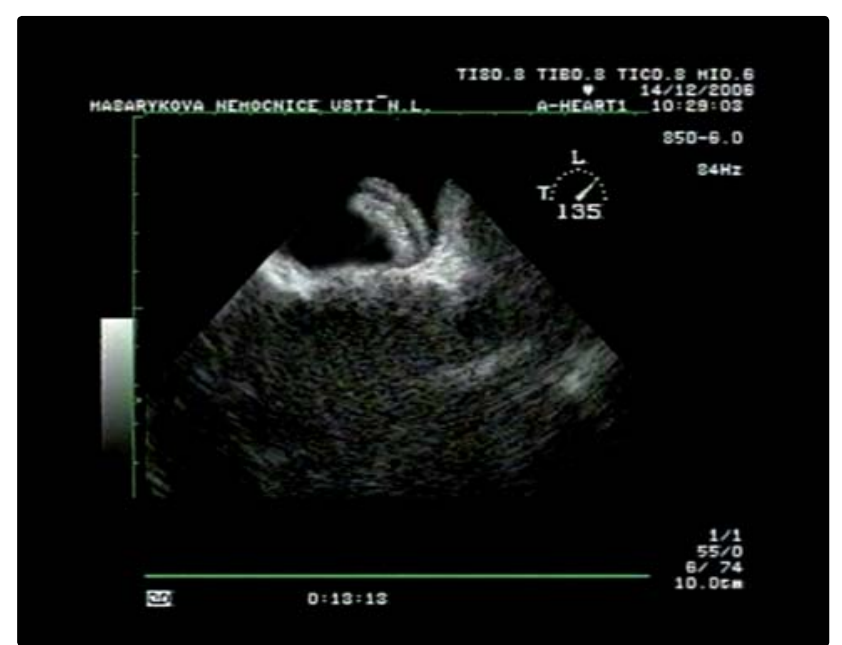

Obrázek 1 Embolizující Amplatzův okluder z mezisíňového septa do levé síně (TEE)

TEE - transesofageální echokardiografie v žádné ze srdečních dutin. Až opakovanou skiaskopií byl zobrazen v břišní krajině. Předpokládaná embolizace okluderu do descendentní aorty byla potvrzena jeho posunutím proximálně po kontaktu s „pig-tail“ katetrem, který byl zaveden přes pravou stehenní tepnu. Pomocí kličky Amplatz Goose Neck ${ }^{\circledast}$ Microsnare $25 \mathrm{~mm}$ (MediMark, Francie) byl okluder zachycen (obrázek 2) a stažen do pravé stehenní tepny. Pokus o perkutánní extrakci embolizovaného zařízení přes širší zavaděč (11 F) z levé stehenní tepny pomocí druhé kličky Microsnare nebyl úspěšný (obrázek 3). $\mathrm{Z}$ toho důvodu byla extrakce okluderu provedena $\mathrm{z}$ malého řezu cévním chirurgem v krátké celkové anestezii (obrázek 4). Nemocný byl propuštěn do domácího ošetřování čtvrtý den po výkonu.

Závěr: Kasuistika popisuje embolizaci Amplatzova okluderu do systémového řečiště. Klíčovým momentem úspěšného řešení této komplikace bylo stažení zařízení do tepny menšího průměru, dobře chirurgicky dostupné, která po neúspěšné snaze o katetrizační odstranění umožnila extrakci okluderu malým operačním výkonem.

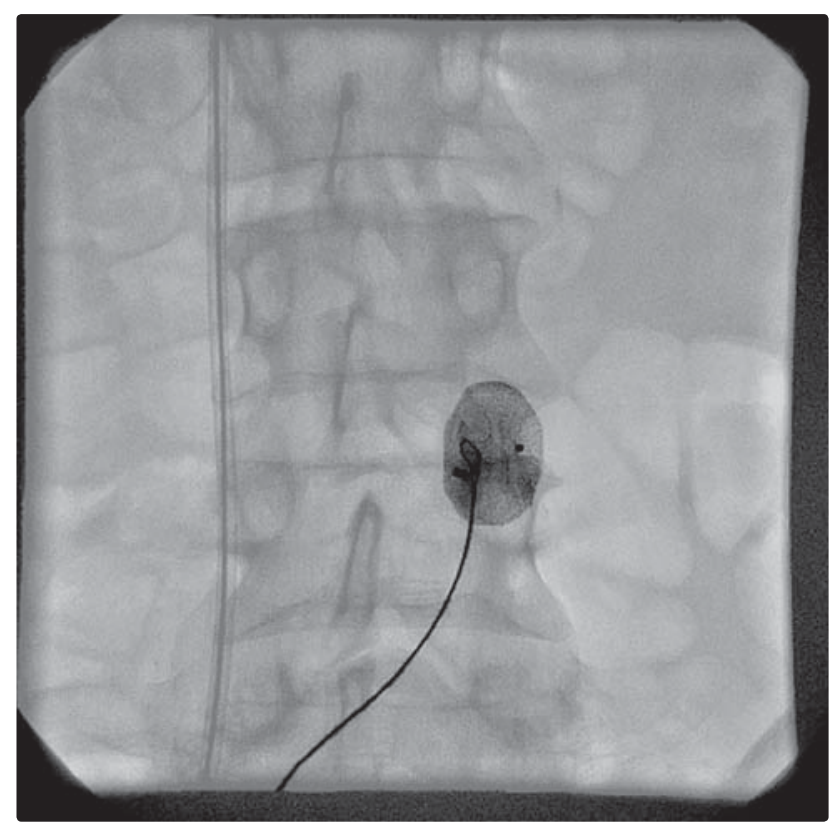

Obrázek 2 Amplatzův okluder zachycený kličkou při skiaskopické kontrole

Adresa: MUDr. Mgr. Martin Běhounek, Kardiologická klinika, Krajská zdravotní a. S., Masarykova nemocnice, Sociální péče 3316/12A, 400 10 Ústí nad Labem, Česká republika martin.behounek@email.cz, martin.behounek@mnul.cz 


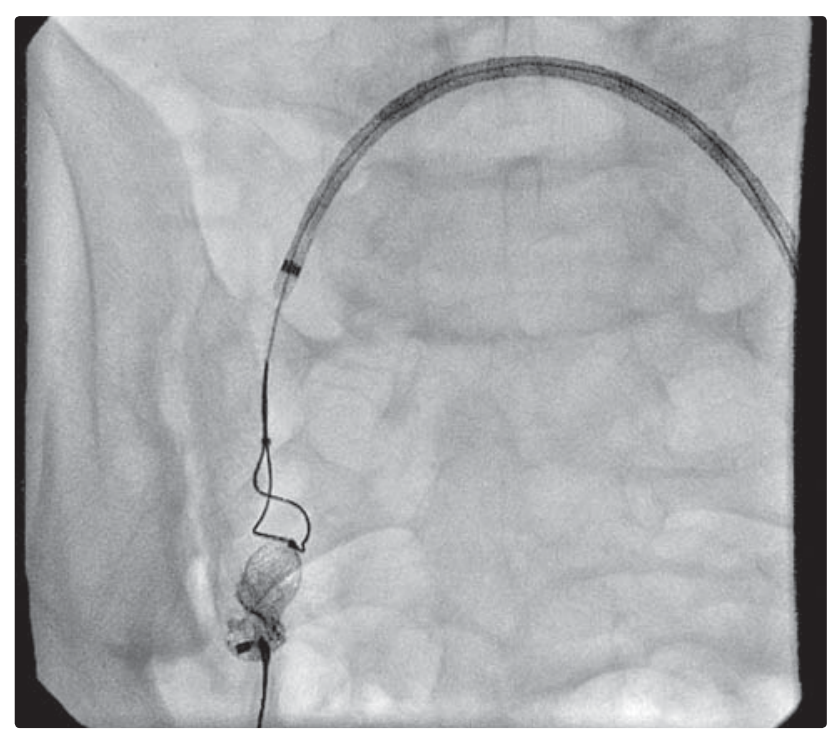

Obrázek 3 Pokus o perkutánní extrakci okluderu pomocí druhé kličky z levé stehenní tepny

\section{Literatura}

1. Popelová J. Vrozené srdeční vady v dospělosti. 1. vydání. Praha: Grada Publishing, 2003:23-33.

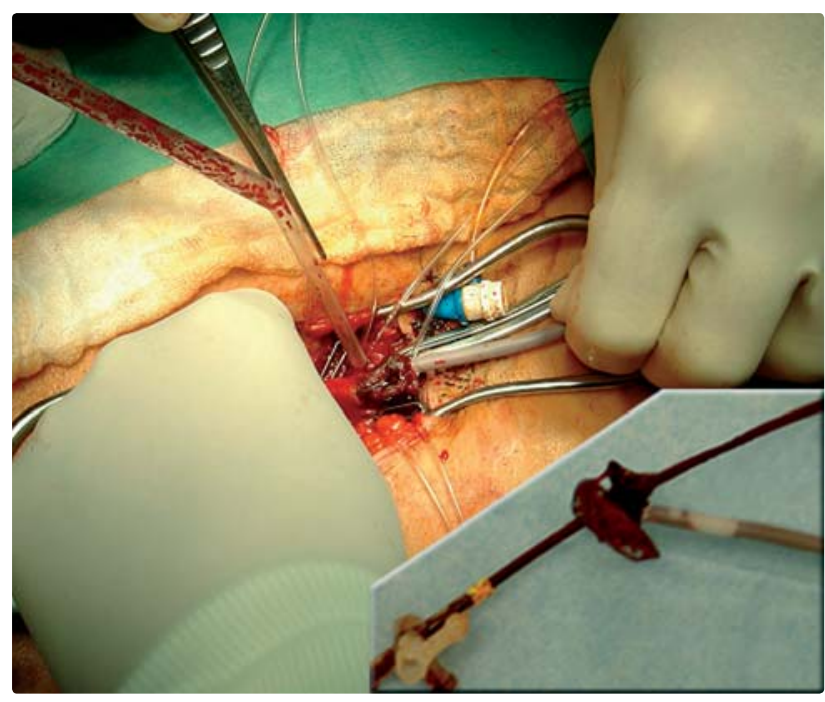

Obrázek 4 Chirurgická extrakce deformovaného Amplatzova okluderu ze společné femorální tepny; vpravo dole je extrahovaný okluder se zavaděčem

2. Quynh A. Truong, Vishal Gupta, Hiram G. Bezerra, et al. The Traveling Amplatzer: Rare Complication of Percutaneous Atrial Septal Occluder Device Embolism. Circulation 2008;118: e93-96e. 